\title{
MANAJEMEN KEWIRAUSAHAAN MELALUI STRATEGI BERBASIS SEKOLAH DI ISLAMIC SOLIDARITY SCHOOL
}

\author{
Isthifa Kemal, Rossy Anggelia Hasibuan \\ STKIP Bina Bangsa Getsempena, Islamic Solidarity School \\ isthifakemal@gmail.com
}

\begin{abstract}
Abstrak
Pemerintah telah berupaya untuk memasyarakatkan kewirausahaan, namun upaya tersebut belum membawa pengaruh yang signifikan karena masih banyak penduduk yang tidak produktif setiap tahun. Dalam praktik di sekolah, bisa di lihat bagaimana strategi mengelola lembaga sekolah dengan menggunakan konsep kewirausahaan yang menguntungkan bagi sekolah dan siswa, dengan cara mengoptimalkan segala potensi yang dimilikinya. Hal ini bisa dilihat dari (1) syarat-syarat apa saja yang harus di miliki pengelola sekolah agar mampu menciptakan unit kewirausahaan, (2) bagaimana pola pengembangan unit kewirausahaan yang dapat di implementasikan di sekolah, (3) bagaimana cara memonitor dan mengevaluasi pengembangan kewirausahaan di sekolah. Sampel pada penelitian ini adalah SMP Islamic Solidarity School yang telah menerapakan kewirausahaan berbasis sekolah. Metode yang digunakan adalah deskriptif dengan memaparkan hasil penelitian. Hasil penelitian yang capai saat ini yaitu, guru belum menerapkan pembelajaran berbasis kewirausahaan dalam perencanaan pembelajaran. Ada beberapa kendala yang dihadapi pihak sekolah dalam menrapkan kewirausahaan berbasis sekolah diantaranya dana, Sumber Daya Manusia, Sarana prasarana, waktu, pemasaran dan kerjasama pada pihak luar yang terkait.
\end{abstract}

Kata kunci: manajemen pendidikan, pendidikan kewirausahaan, strategi berbasis sekolah

\section{MANAGEMENT STRATEGIES BASED ENTREPRENEURSHIP THROUGH SCHOOLS IN ISLAMIC SOLIDARITY SCHOOL}

\author{
Isthifa Kemal, Rossy Anggelia Hasibuan \\ STKIP Bina Bangsa Getsempena, Islamic Solidarity School \\ isthifakemal@gmail.com
}

\begin{abstract}
The government has made an effort to promote entrepreneurship, but these effort seem not show a significant impact due to the fact that many people who are not productive every year. It can be seen at school practice how the management of school institutions apply the concept of entrepreneurship that is benefical for schools and students by optimizing its potential. This can bee seen from (1). The requirements that should be owned by the school manager to be able to create an entrepreneurial unit, (2). How to develop of entrepreneurial units that can be implemented in school, (3). How to monitor and evaluate the development of entrepreneurship in schools. The sample of this study is Islamic Junior High School (Solidarity School) that has been applying the school-based entrepreneurship. This is a qualitative method using descriptive approach. The current research results are the teachers have not applied a based learning entrepreneurship in lesson planning. There are several problems faced by the school in applying the school-based entrepreneurship namely: funding, human resources, facilities and infrastructure, time, marketing, and cooperation on relevant external parties.
\end{abstract}

Keywords: education management, entrepreneurship education, school-based strategies 


\section{Pendahuluan}

Menurut Hastuti, (2009) pendidikan untuk pengembangan berkelanjutan adalah sebuah paradigma baru, di bidang pendidikan (formal, nonformal dan informal) yang mempertimbangkan 3 dimensi yaitu kesinambungan ekonomi, keadilan sosial (termasuk kultur dan budaya), dan kelestarian lingkungan secara simultan dan berkelanjutan. Permasalahan pendidikan yang kita hadapi adalah rendahnya mutu pendidikan di setiap jenjang pendidikan dari pendidikan dasar hingga menengah (Bustami, 2009). Menurut Komalasari (2011) rendahnya mutu pendidikan karena menghasilkan siswa yang tidak mampu menerapkan hasil pembelajaran yang diperoleh dari sekolah dalam kehidupan sehari-hari ataupun sebaliknya.

Undang-Undang No. 20 Tahun 2003 tentang Sistem Pendidikan Nasional Pasal 3, menyatakan bahwa pendidikan nasional berfungsi mengembangkan kemampuan dan membentuk watak serta peradaban bangsa yang bermartabat dalam rangka mencerdaskan kehidupan bangsa, bertujuan untuk mengembangkan potensi peserta didik agar menjadi manusia yang beriman dan bertakwa kepada Tuhan Yang Maha Esa, berakhlak mulia, sehat, berilmu, cakap, kreatif, mandiri, dan menjadi warga negara yang demokratis serta bertanggung jawab (Depdiknas, 2003).

Berkaitan dengan ketercapaian tujuan pendidikan nasional terutama yang mengarah pada pembentukan karakter yang terkait dengan pembentukan sikap dan perilaku wirausaha peserta didik, selama ini belum dapat diketahui secara pasti. Hal ini mengingat pengukurannya cenderung bersifat kualitatif, dan belum ada standar nasional untuk menilainya. Berlakunya sistem desentralisasi berpengaruh pada berbagai tatanan kehidupan, termasuk pada manajemen pendidikan yaitu manajemen yang memberi kebebasan kepada pengelolaan pendidikan. Adanya kebebasan dalam pengelolaan pendidikan diharapkan mampu menemukan strategi pengelolaan pendidikan yang lebih baik sehingga mampu menghasilkan output pendidikan yang berkualitas baik dilihat dari kualitas akademik maupun non akademik. Kualitas akademik yang dimaksud adalah kualitas peserta didik yang terkait dengan bidang ilmu, sedangkan kualitas non-akademik berkaitan dengan kemandirian untuk mampu bekerja di kantor dan membuka usaha/lapangan kerja sendiri. Dengan kata lain lulusan pendidikan diharapkan memiliki karakter dan perilaku wirausaha yang tinggi.

Engkoswara (1999), menyatakan bahwa kehidupan manusia Indonesia menjelang tahun 2020 akan semakin membaik dan dinamik. Untuk itu kualitas lulusan dituntut memiliki kemampuan kemandirian yang tangguh agar dapat menghadapi tantangan, ancaman, hambatan yang diakibatkan terjadinya perubahan. Lebih lanjut dikemukakan bahwa tantangan yang terjadi pada era Global adalah semakin menipisnya kualitas kemandirian manusia Indonesia. Krisis yang melanda Indonesia yang multidimensi mengakibatkan budaya bangsa semakin memudar, yaitu terjadinya degradasi moral spiritual, semangat berusaha dan bekerja yang semakin melemah, kreativitas yang semakin mengerdil dan menjurus ke arah yang negatif. Melalui pengembangan individu diharapkan secara keseluruhan masyarakat akan mengalami "self empowering" untuk lebih kreatif dan inovatif. Kecenderungan terjadinya perubahan tidak dapat dihindari semua pihak, baik individu, kelompok masyarakat, bangsa, maupun negara, sehingga dituntut untuk lebih memfokuskan diri pada penyusunan rencana strategik dengan visi yang jauh ke depan agar siap menghadapi setiap perubahan. Realita yang ada, banyak lulusan pendidikan yang tidak mampu mengisi lowongan pekerjaan karena ketidakcocokan antara kemampuan yang dimiliki dengan kemampuan yang dibutuhkan dunia kerja. Di samping itu penyerapan tenaga kerja oleh instansi pemerintah maupun swasta yang sangat terbatas, akan memberi dampak jumlah tingkat pengangguran akan meningkat pada setiap tahunnya.

Sekolah membutuhkan para pengelola yang miliki jiwa wirausaha tangguh, 
yang tidak hanya mengandalkan dana BOS dari Pemerintah dengan konsekuensi ketat namun mampu memaksimalkan potensi lembaga yang dipimpinnya menggunakan konsep wirausaha yang menghasilkan laba (profit taking) namun dalam koridor yuridis yang berlaku. Pada akhirnya nanti, konsep tersebut akan memberikan kecukupan modal yang diperlukan untuk menunjang proses pendidikan dari lembaga sekolah serta memberi pengetahuan dan keterampilan kewirausahaan bagi siswa yang berguna jika telah hidup di masyarakat kelak.

Menghubungkan suatu penelitian dengan penelitian terdahulu yang relevan adalah suatu usaha dalam rangka menemukan validitas hasil penelitian yang reliabel dan terpercaya, maka untuk menyelaraskan hasil penelitian dalam rangka mencari relevansi antara penelitian terdahulu adalah dengan melihat yang dijabarkan.

Di sisi lain pengetahuan tentang hasil penelitian terdahulu adalah menjadi penting sebagai titik permulaan dan sebagai landasan awal dalam melakukan penelitian selanjutnya. Dengan demikian akan menemukan perkembangan-perkembangan baru dalam melakukan penelitian yang dapat menjadi bahan pertimbangan.

Pengembangan kreativitas dan inovasi sebagai basis kewirausahaan sekolah merupakan ikon baru bagi kepala sekolah bersama warga sekolah. Kewirausahaan sekolah dipahami sebagai kernarnpuan kreatif dan inovatif yang dijadikan dasar, kiat dan sumber daya untuk mencari dan memanfaatkan peluang menuju sukses. Seperti yang dikemukakan oleh Dharma \& Akib (2009), inti kewirausahaan sekolah adalah kemampuan kepala sekolah bersama warga sekolah untuk menciptakan sesuatu yang baru, unik, berbeda atau bermakna (bernilai) melalui pemikiran kreatif dan tindakan inovatif demi terciptanya peluang, ruang dan uang. Tiga dari empat strategi pengembangan kreativitas dan inovasi, selain strategi pengaruh minoritas relevan diterapkan di sekolah yakni strategi eklektif, strategi pemaksaan kekuasaan dan strategi partisipatif.
Hal ini menunjukkan bahwa kepala sekolah sebagai pimpinan pada sebuah sekolah mempunyai peranan penting dalam memajuka kewirausahaan di lingkungan sekolah. Kepala sekolah harus lebih kreatif dan inovatif dalam mengembangkan unit-unit usaha yang ada dalam lingkungan sekolah guna meningkatkan kesejahteraan seluruh civitas sekolah. Hal serupa juga diungkapkan oleh Samino (2013) dalam penelitiannya yang berjudul Peran Kepala Sekolah Terhadap Pengembangan Kewirausahaan dalam Memajukan SD Muhammadiyah Program Khusus Kota Barat.

Hasil penelitian menunjukkan bahwa kepala sekolah SD Muhammadiyah Kota barat membuat perencanaan program kewirausahaan yang akan dilaksanakan masing-masing bidang, selain itu kepala sekolah juga ikut berperan langsung ke lapangan baik dalam melaksanakan unit usaha maupun mengevaluasi hasil penanggung jawab masing-masing unit usaha.

Dapat disimpulkan bahwa untuk memajukan sekolah terdapat sesuatu yang sangat urgen yaitu motivasi, selanjutnya dalam merencanakannya kepala sekolah memunculkan gagasan tentang pengembangan kewirausahaan, kemudian dimusyawarahkan dengan segenap guru dan karyawan untuk mendapatkan kesepakatan. Setelah rumusan pengembangan kewirausahaan disepakati maka semuanya berkomitmen untuk melaksanakan dengan sebaik-baiknya.

Dalam menindaklanjuti perencanaan kepala sekolah ikut berperaan aktif, sehingga ikut terjun di tengah-tengah lapangan. Dalam perjalanannya kepala sekolah selalu menciptakan komunikasi yang interaktif, memberikan semangat dan motivasi untuk bekerja keras serta bekerja sama yang baik untuk mencapai keberhasilan.

Dalam mengevaluasi seluruh program pengembangan kewirausahaan untuk memajukan sekolah dilakukan evaluasi secara rutin dan insidental atau secara terprogram dan temporar. Evaluasi rutin atau terprogram dilaksanakan secara periodik dan evaluasi insidental dilaksanakan sesuai dengan situasi dan kondisi. Hal sena- 
da juga diungkapkan oleh Ngadi (2005), pola pengembangan kewirausahaan sekolah meliputi tahap persiapan, yaitu mengidentifikasi lingkungan dan peluang jenis usaha di masyarakat di sekitar sekolah. Selanjutnya tahap perencanaan, yang meliputi analisis potensi serta kemungkinan pengembangannya. Tahap pelaksanaan, dapat ditempuh dengan jalan mendirikan unit produksi/jasa kewirausahaan, memberikan pendidikan dan pelatihan kewirausahaan terhadap siswa. Dan tahap monitoring dan evaluasi yang dilakukan oleh Kepala Sekolah bersama Komite Sekolah atau institusi usahad mitra terkait dan dilaksanakan sepanjang tahun secara periodik.

Beberapa hasil penelitian yang telah dikemukakan dapat diambil kesimpulan bahwa, kewirausahaan di sekolah dapat berjalan dengan baik dan berkembang bila kepala sekolah maupun pimpinan sekolah memiliki ide yang kreatif dalam pengembangan unit-unit usaha yang ada di sekolah. Pimpinan sekolah harus senantiasa memberikan motivasi dengan komunikatif kepada setiap guru maupun siswa yang berperan dalam unit usaha serta terjun langsung kelapangan dalam hala pengembangan kewirausahaan di sekolah. Kepala sekolah juga harus memonitor dan mengevaluasi kegiatan kewirausahaan sekolah secara periodik sehingga dapat mengetahui kendala sedini mungkin sehingga dapat meminimalisir kerugian di unit-unit usaha. Usaha tersebut akan memberikan kecukupan modal yang diperlukan menunjang proses pendidikan dari lembaga sekolah serta memberi pengetahuan dan keterampilan kewirausahaan bagi siswa yang berguna jika telah hidup di masyarakat kelak.

\section{Metode Penelitian}

Penelitian menggunakan metode kualitatif, hal ini didasarkan kepada rumusan masalah penelitian yang menuntut peneliti melakukan eksplorasi dalam memahami dan menjelaskan masalah yang diteliti melalui hubungan yang intensif dengan sumber data. Dalam penelitian ini peneliti mengumpulkan data deskripsi mengenai kegiatan atau perilaku subjek yang diteliti, baik persepsinya maupun pendapatnya serta aspek-aspek lain yang relevan melalui kegiatan wawancara, observasi dan studi dokumentasi. Menurut Bogdan dan Taylor seperti dikutip Moleong (2001) mengatakan bahwa penelitian kualitatif pada latar belakang ilmiah sebagai kebutuhan mengandalkan manusia sebagai alat penelitian, memanfaatkan metode kualitatif dan menganalisis data secara indukatif"

Dari pernyataan tersebut memberi gambaran bhawa penelitian kualitatif lebih mengutamakan manusia sebagai subjek penelitian dan lebih memfokuskan kepada proses daripada hasil. Melalui analisis induktif penelitian pengungkapan makna dari keadaan yang diamatinya, sedangkan untuk menjawab permasalahan secara teoretis digunakan studi kepustakaan, dengan ini diharapkan penganalisisan terhadap beberapa variabel yang dijadikan faktor penelitian lebih akurat.

\section{Hasil Penelitian dan Pembasan}

Setelah melakukan penelitian pertama ke SMP ISS diperoleh beberapa data bahwa ada 7 (tujuh) unit usaha yang ada di ISS yaitu kooperasi sekolah, budidaya jamur, teh, roti, tata boga, percetakan, perkebunan jambu biji, dan perkebunan sengon. Dari segi perencanaan guru-guru di SMP ISS belum menerapkan kegiatan kewirausahaan dalam RPP, hal ini di karenakan guru-guru berasumsi bahwa tidak semua pelajaran dapat dilakukan dengan kegiatan kewirausahaan. Penerapan kewirausahaan di SMP ISS juga mengalami beberapa kendala diantaranya waktu, kemampuan SDM dan kerja sama dalam hal pemasaran.

Peneliti melakukan penelitian lebih lanjut mengenai Syarat-Syarat Mendirikan Unit Kewirausahaan, Pola Pengembangan Kewirausahaan Berbasis Sekolah, dan Cara Memonitor dan Mengevaluasi Kewirausahaan di Islamic Solidarity School. Diperoleh hasil sebagai berikut. 
Syarat-Syarat Mendirikan Unit Kewirausahaan di Islamic Solidarity School

Melalui wawancara yang dilakukan pada Manajer Kewirausahaan di SMP ISS yaitu Abi Ainul Yaqin, Abi Ainul Yaqin yang selama ini mengelola semua unit usaha yang ada di SMP ISS dan dibantu oleh para penanggung jawab setiap unit usaha dan siswa SMK Grafika ISS. Abi Ainul biasa ia dipanggil, bukanlah orang berlatarbelakang pengusaha maupun pendidikan dibidang bisnis bahkan ekonomi. Abi Ainul sendiri merupakan alumni dari pondok pesantren An Nu'aimi di Jakarta, beliau mengambil jurusan Pendidikan Agama Islam. Begitu pula para penanggung jawab masing-masing unit usaha yang merupakan latar belakang pendidikan bukan ekonomi maupun bisnis.

Syarat berhasil atau tidaknya suatu unit usaha menurut abi Ainul sendiri adalah kemauan dan keberanian untuk melakukan sesuatu yang baru dan inovatif untuk menghasilkan sesuatu yang lebih baik. Meski pendidikan juga perlu namun tanpa kemauan dan keberanian untuk memulai berwirausaha maka kita tidak akan pernah berhasil. Pendidikan berperan untuk mengetahui teknik berwirausaha, dan wawasan kita dalam melihat kebutuhan pasar sehingga dapat memperoleh ide kreatif yang membantu usaha yang akan kita jalankan. Bila tidak memiliki pendidikan yang sesuai dengan bisnis dapat diatasi dengan mengikuti berbagai pelatihan tentang kewirausahaan atau bisnis.

Sebagai manajer wirausaha abi ainul juga harus mengetahui kemampuan dana dari yayasan dalam pengembangan unitunit usaha, unit usaha yang berada di sekolah sebagai manajer wirausaha juga harus mengetahui kebutuhan siswa setiap hari, minggu bahkan bulanan siswa agar siswa tidak lagi membeli kebutuhan seharihari di luar sekolah. Dengan begitu maka unit usaha yang ada di sekolah dapat memperoleh keuntungan yang besar dari hasil penjualan.
Keberhasilan sebuah unit usaha juga dapat berjalan dengan baik jika dalam pengelolaannya diberi secara penuh dan sikap saling percaya antara pemilik dana, pengelola dan penanggung jawab tiaptiap unit usaha yang ada di SMP ISS. Dengan kepercayaan yang diberikan pemilik dana terbesar dalam hal ini adalah yayasan Baitul Maal Muamalat sehingga akan memberi kenyamanan bagi manajer wirausaha untuk mengembagkan unit usaha yang ada di SMP ISS. Begitu juga jika manajer wirausaha yang memberikan kepercayaan kepada tiap-tiap unit usaha untuk memproduksi maupun memasarkan hasil produksi dengan baik.

Sikap jujur dan bertanggung jawab atas amanah yang diberikan oleh seseorang juga merupakan syarat untuk menjalankan suatu usaha. Dengan sikap bertanggung jawab kita akan lebih gigih dalam mengembangkan unit usaha karena itu merupakan titipan masyarakat sekolah karena di SMP ISS guru-guru dan karyawan juga ikut terlibat dalam penanaman modal di beberapa unit usaha seperti Koperasi, Kafe, Perkebuanan Jambu Biji Merah dan Sengon. Banyak orang ikut berperan dalam kemajuan unit usaha di SMP ISS sehingga sikap tanggung jawab sangat dibutuhkan.

Kejujuran juga merupakan modal utama dalam pengembangan unit usaha di SMP ISS. Melalui kejujuran maka unit usaha ini berjalan dengan baik, selain itu sikap jujur yang diciptakan di lingkungan SMP ISS juga akan menjadi pembelajaran bagi guru, karyawan dan terutama siswasiswi yang berada di ISS. Banyak siswa yang diikut sertakan dalam hal produksi di tiaap-tiap unit usaha yang ada di ISS, diantaranya penjaga koerasi dan kafe, pembuatan teh, siomai, tataboga, pemanenan jamur hingga jambu biji merah. Bila tidak ada kejujuran yang dimiliki siswa maka tidak menutup kemungkinan jika siswa membelanjakan uang hasil produksi maupun hasil dagang.

Selain sebagai pembelajaran bagi siswa kejujuran juga sangat berperan dalam hal kepercayaan orang lain terhadap kinerja manajer wirausaha dan penanggung ja- 
wab unit usaha yang ada di SMP ISS karena ini menyangkut kemaslahatan orang banyak. Abi Ainul sendiri percaya bahwa dengan sikap jujur yang tertanam didalam diri tiap-tiap pengelola unit usaha akan menambah berkah dari Allah SWT sehingga unit usaha ini akan menjadi berkah.

Berdasarkan hasil wawancara yang dilakukan dapat disimpulkan bahwa syarat-syarat mendirikan Unit Kewirausahaan di SMP ISS adalah keberanian dan kemauan, pendidikan dan pelatihan tentang kewirausahaan, sikap saling percaya, bertanggung jawab dan kejujuran. Hal senada juga diungkapkan oleh Ngadi (2005) yaitu seorang pengelola sekolah yang berjiwa wirausaha hendaknya memiliki karakteristik antara lain sebagai berikut: (1) terampil mengidentifikasi lingkungan dan peluang di masyarakat; (2) terampil mengidentifikasi segala potensi dan kemampuan sekolah yang dikelolanya; (3) terampil mengidentifikasi kondisi sosial budaya dan potensi ekonomi masyarakat di sekitar sekolah yang dikelolanya; (4) terampil menganalisis potensi (komoditas unggulan dan penerapan teknologi praktis) serta kemungkinan pengembangannya ke depan; (5) terampil memilih jenis kewirausahaan yang tepat dan dipercaya dapat berkembang ke depan dan merealisasikan (mendirikan) dalam bentuk unit usaha yang profit taking serta berani mengambil resiko dari usaha yang didirikan tersebut; (6) mampu meyakinkan dan memberikan pelayanan memuasakan berbagai pihak terkait serta sanggup memecahkan masalah meskipun ke luar dari sistem; (7) memiliki akhlak mulia yaitu tidak mengambil manfaat dari unit usaha yang dikembangkan untuk kepentingan pribadi, melainkan ingin menumbuhkan iklim sekolah yang bergairah dan produktif, menyejahterakan sivitas akademik, mengembangkan ekonomi kerakyatan, serta menciptakan masyarakat madani

Pola Pengembangan Kewirausahaan Berbasis Sekolah di Islamic Solidarity School

Hasil wawancara yang dilakukan kepada manajer kewirausahaan diperoleh keterangan bahwa dalam melakukan pengembangan kewirausahaan di ISS tidak ada pola khusus melainkan menggunakan pola kebanyakan yang dipakai oleh perusahaan-perusahaan lainnya, hanya saja caranya saja yang bervariasi. Ada 4 (empat) tahapan yang dilakukan saat akan melakukan pengembangan kewirausahaan yang ada di ISS, yaitu tahapan persiapan, tahapan perencanaan, tahapan pelaksanaan, dan tahapan pemasaran.

Tahapan persiapan yang perlu dilakukan adalah mengunjungi pasar tradisional yang ada disekitar sekolah untuk melihat kebutuhan masyarakat terhadap suatu benda ataupun sesuatu yang belum ada dipasaran tetapi memiliki nilai jual tinggi seperti jamur tiram. Di Kota Jantho masih sangat jarang sekali petani jamur tiram, sementara peminat jamur tiram sendiri cukup banyak. Setelah mendapatkan informasi tentang potensi jual yang akan dilakukan, langkah selanjutnya adalah memprediksi kemampuan yayasan ataupun para penanam modal yang ada di ISS untuk melaksanakan ide usaha.

Tahapan perancangan yang biasa dilakukan yaitu dengan mengunjungi lembaga maupun institusi yang sesuai dengan kebutuhan misalnya mengunjungi petani jamur itu sendiri untuk menganalisa potensi keuntungan maupun kegagalan yang akan di hadapi. Selain petani jamur manajer wirausaha juga mengunujungi berbagai pengusaha-pengusaha yang ada di Banda Aceh untuk mempelajari wirausaha apa yang dapat diterapkan di ISS.

Sebelum membuat proposal terlebih dahulu pada tahapan ini kita akan berdiskusi dengan para guru, dan project manajer dalam hal ini di percayakan kepada Abi Gunawan Indra Hasibuan, M.A untuk memilih dan menentukan jenis wirausaha apa yang akan diterapkan di ISS. Langkah terakhir pada tahapan ini adalah pembuatan proposal pengajuan anggaran biaya untuk melaksanakan kegiatan wirausaha yang telah disepakati.

Tahapan pelaksanaan biasa dilakukan pelatihan bagi siswa yang akan terlibat langsung dalam hal produksi, misalnya 
kita akan mendatangkan tukang bakso untuk mengajarkan penanggung jawab dan siswa dalam pembuatan siomai. Siswa dan penanggung jawab akan dibawa training ke serambi bagi yang terlibat dalam hal percetakan, danseterusnya. Setelah mendapat pelatihan siswa yang diarahkan oleh penanggung jawab setiap unit usaha akan memulai mempraktikkan apa yang telah dipelajari pada jam tidak efektif sekolah atau setelah pulang sekolah.

Tahap pemasaran, biasanya dilakukan oleh manajer kewirausahaan yang dibantu oleh siswa SMK yang putra dan putri. Dalam hal pemasaran manajer kewirausahaan mengalami beberapa kesulitan karena menurut beliau pemasaran ini membutuhkan kemampuan khusus sehingga konsumen menjadi lebih tertarik untuk membeli produk yang ditawarkan . kemampuan yang harus dimiliki bagaimana orang yang melakukan pemasaran harus dapat menjual mutu dan memahami kemapuan konsumen terhadap harga dari sebuah produk yang akan ditawarkan.

Pola pengembangan yang diungkapkan oleh manajer kewirausahaan ISS yaitu tahapan persiapan, perencanaan, pelaksanaan dan pemasaran sama halnya yang dikemukakan oleh Depdiknas (1998; 2001), pola pengembangan kewirausahaan meliputi beberapa tahapan, diantaranya adalah sebagai berikut.

\section{Tahap Persiapan}

Tahap ini meliputi beberapa langkah sebagai berikut. Pertama, adalah mengidentifikasi lingkungan dan peluang jenis usaha di masyarakat. Langkah ini adalah pemikiran kreatif dalam menemukan ideide wirausaha yang akan menciptakan dan menambah nilai tambah, serta menggambarkan keadaan operasi pada masa kini dan akan datang (Depdiknas, 1998, p. 3). Dalam praktik, jumlah peluang adalah lebih dari satu macam sehingga jenis usaha yang didentifikasi juga lebih dari satu macam.

Kedua adalah mengidentifikasi potensi dan kemampuan sekolah, yaitu menemukan fungsi-fungsi yang dipakai un- tuk merealisasikan peluang, antara lain dengan memperhatikan: jumlah personel sekolah, jumlah siswa, sarana prasarana, penggunaan teknologi praktis, komoditi unggulan, transportasi, pemasaran dan lain-lain yang berhubungan dengan kewirausahaan yang akan dikembangkan.

Ketiga, identifikasi kondisi sosial budaya dan potensi ekonomi masyarakat di sekitar sekolah, yaitu menemukan karakteristik masyarakat yang berhubungan dengan kewirausahaan yang akan dikembangkan, meliputi sosial, budaya, tingkat ekonomi dan pendidikannya, serta lainnya.

\section{Tahap Perancangan}

Tahap ini melalui beberapa langkah sebagai berikut. Pertama, analisis potensi serta kemungkinan pengembangannya, yaitu menganalisis segala potensi di atas (fungsi-fungsi untuk mengembangkan kewirausahaan) dengan mempertimbangkan aspek kekuatannya (strength), kelemahannya (weakness), peluangnya (opportunity), dan ancaman (threats).

Kedua, memilih dan menetapkan jenis kewirausahaan, dimana manakala potensi dan peluang lebih banyak didukung aspek strength dan opportunity, maka jenis kewirausahaan sekolah dapat dipilih dan ditetapkan sebab dipercaya berkembang ke depan. Agar efektif, dalam memilih jenis usaha dapat bekonsultasi dengan klub kewirausahaan, Komite Sekolah, alumni, donatur, Pemda, sponsorship, atau lembaga lain.

Ketiga, kunjungan institusi usaha lokal relevan/sejenis yang berfifat kerakyatan, dimana untuk memberikan gambaran tentang peluang dan kendala-kendala pengembangan ke depan, dan atau menciptakan ide-ide usaha baru yang lebih produktif.

Keempat, simulasi dan penyusunan proposal kewirausahaan, dilakukan penyelenggara kewirausahaan sekolah setelah melakukan kunjungan institusi usaha lokal guna mendiskusikan beberapa hal sehingga dapat ditentukan model pengembangan kewirausahaan terpilih ke depan yang lebih baik. Sementara itu, dilanjutkan de- 
ngan menulis proposal kewirausahaan yang berisikan tentang jenis usaha yang akan dirikan, manfaat, prosedur kerja serta alokasi dana, perkiraan produksi dan keuntungan, pelaksana, dan atau lainnya yang siap dilaksanakan dan ditujukan kepada pihak-pihak terkait, guna mendapatkan bantuan modal usaha, seperti Pemda, unit usaha mitra, sponsorship, donatur, alumni, Komite Sekolah, badan lembaga nasional dan internasional, atau lainnya dengan syarat tidak mengikat terhadap penggunaan profit unit usaha produksi/ jasa sekolah ke depan.

\section{Tahap Pelaksanaan}

Tahap ini meliputi beberapa langkah sebagai berikut. Pertama, mendirikan unit produksi/jasa kewirausahaan, yaitu membuat unit usaha profit taking yang melayani customer umum, dan keuntungannya digunakan untuk mendukung kecukupan modal dalam rangka efektifitas proses lembaga sekolah serta berkembang ke depan. Agar efektif, dalam mendirikan unit produksi/jasa dapat bekonsultasi dengan klub kewirausahaan, Komite Sekolah, alumni, donatur, Pemda, sponsorship, atau lembaga lain, sehingga dapat diperoleh rancangan strategis serta mendapatkan dukungan operasional.

Kedua, pendidikan dan pelatihan kewirausahaan terhadap siswa, dimana dilakukan dalam bentuk kegiatan kurikuler, kokurikuler, dan atau ekstrakurikuler, baik secara reguler (klasikal) atau merupakan program pilihan dalam bentuk klub kewirausahaan mikro. Materi pendidikan dan pelatihan kewirausahaan siswa meliputi manajemen produksi dan pemasaran komoditi unggulan sesuai potensi daerah, kemampuan berusaha, daya saing, pelayanan prima, pengelolaan ke-uangan tingkat sederhana, serta pengembangan kreativitas dan inovasi (Depdiknas, 2001, pp. 9-10).

Ketiga, praktik kewirausahaan siswa, dilaksanakan setelah siswa memperoleh pendidikan dan pelatihan kewirausahaan teoritis di kelas dan dimaksudkan agar ilmu kewirausahaan yang telah siswa peroleh dari lembaga sekolah dapat diimplementasikan dalam dunia nyata (real life) yang empirik. Selain itu, siswa juga terangsang dapat menemukan kendalakendala dan potensi unit usaha yang diamati sehingga diharapkan dapat menemukan ide-ide usaha baru yang dapat diadobsi kelak. Praktik kewirausahaan siswa dapat dilakukan secara langsung pada unit usaha yang dikembangkan sekolah sendiri atau dilakukan pada unit usaha mitra dalam bentuk latihan kerja atau on the job trainning (OJT) yang dilaksanakan diluar hari efektif kelas reguler (semisal efektif fakultatif) dalam jalinan kerja dual system education sehingga akan tercapai link and match antara ilmu yang diajarkan di sekolah dengan unit usaha masyarakat.

\section{Tahap Pemasaran}

Kotler (1997) mengemukakan bahwa terdapat 5 (lima) konsep yang dapat dipilih oleh perusahaan untuk melaksanakan kegiatan pemasarannya, yaitu sebagai berikut.

Pertama, Konsep Produksi yang merupakan salah satu konsep tertua dalam bisnis. Konsep produksi menyatakan bahwa konsumen akan menyukai produk yang tersedia di banyak tempat dan ditawarkan dengan harga yang murah. Asumsi ini berlaku paling tidak dalam dua situasi. Pertama, jika permintaan atas produk melebihi penawaran, dimana konsumen lebih tertarik mendapatkan produk daripada keistimewaan produk tersebut. Kedua, ketika biaya produk tinggi dan harus diturunkan untuk memperluas pasar. Pusat perhatian perusahaan pada upaya untuk mencapai efi-siensi produksi yang tinggi dan distribusi yang luas.

Kedua, Konsep Produk yang menyatakan bahwa konsumen akan menyukai produk yang menawarkan mutu, kinerja dan pelengkap inovatif yang terbaik. Dengan konsep ini, perusahaan memusatkan perhatian pada usaha untuk menghasilkan produk yang unggul dan terus menyempurnakannya.

Ketiga, Konsep Penjualan yang menyatakan bahwa konsumen jika diabaikan, 
biasanya tidak akan membeli produk perusahaan dalam jumlah yang cukup. Olehnya itu, perusahaan harus melakukan upaya penjualan dan promosi yang agresif.

Keempat, Konsep Pemasaran merupakan konsep yang menentang tiga konsep sebelumnya. Konsep ini menyatakan bahwa kunci untuk meraih tujuan perusahaan adalah menjadi lebih efektif daripada pesaing dalam memadukan kegiatan pemasaran guna menetapkan dan memuaskan kebutuhan dan keinginan konsumen sebagai pasar sasaran.

Kelima, Konsep Pemasaran Berwawasan Sosial merupakan perluasan dari konsep pemasaran. Konsep ini menyatakan bahwa tugas perusahaan adalah menentukan kebutuhan, keinginan dan kepentingan pasar sasaran dan memberikan kepuasan yang diinginkan secara lebih efektif dan efisien daripada pesaing dengan mempertahankan dan meningkatkan kesejahteraan konsumen dan masyarakat. Konsep ini mengajak para pemasar membangun pertimbangan sosial dan etika dalam praktik pemasaran mereka, karena sering terjadi konflik kepentingan antara kepentingan untuk meningkatkan laba perusahaan, kepentingan untuk memberikan kepuasan kepada konsumen, serta perhatian kepada kepentingan publik.

Cara Memonitor dan Mengevaluasi Kewirausahaan Di Islamic Solidarity School

Hasil wawancara yang dilakukan diperoleh bahwa monitoring bertujuan untuk mengetahui apakah program kewirausahaan sekolah berjalan sesuai rencana (dalam proposal) semula atau tidak, sehingga dapat diketahui apa hambatan yang terjadi serta bagaimana seharusnya pengelola kewirausahaan sekolah mengatasi masalah tersebut. Sedangkan evaluasi bertujuan untuk mengetahui apakah kewirausahaan dapat mencapai tujuan atau tidak, yaitu menghasilkan profit yang dapat digunakan memperkuat modal sekolah dalam rangka meningkatkan proses pembelajaran di sekolah, meningkatkan gairah dalam penyelenggaraan proses pendidikan, mening- katkan produktifitas kerja serta menyejahterakan sivitas sekolah.

Kegiatan monitoring dapat dilakukan oleh Projek Manajer, Para Manajer, atau penanam modal usaha yang terkait dan dilaksanakan sepanjang tahun secara periodik, baik mingguan, bulanan, caturwulan, semester, atau tahunan, sehingga sedini mungkin dapat mengetahui kendala yang muncul serta segera membantu pelaksana kewirausahaan sekolah dalam mencari pemecahannya. Selama ini monitoring yang dilakukan belum menggunakan instrumen yang valid dan reliabel. Namun demikian, kegiatan monitoring dan evaluasi yang dilaksanakan belum sesuai dengan prosedur yang tepat.

Kegiatan monitoring yang selama ini dilakukan hanya pemaparan berapa dana awal yang digunakan, penggunaan untuk apa saja, berapa kerugian yang dialami selama masa produksi. Setelah melakukan penjualan hasil produk berapa dana yang diperoleh, lalu berapa keuntungan yang diperoleh setiap bulannya. Abi Ainul sendiri menyadari bahwa kegiatan monitoring di ISS masih kurang dari standart yang berlaku, namun ini terus berjalan di karenakan rasa saling percaya yang dimiliki oleh pihak pemberi dana dan pengelola yang terjalin dengan baik. Untuk kedepan akan di sesuaikan dengan standar evaluasi kewurausahaan.

Menurut Mahfud \& Pardjono (2012) ada dua cara me-monitoring kewirausahaan yaitu monitoring kinerja dan monitoring produk. Sedangkan Ngadi (2005) mengatakan bahwa kegiatan monitoring dan evaluasi hendaknya mencakup lima aspek, yaitu (1) konteks, (2) input, (3) proses, (4) output, dan (5) outcome. Pertama, aspek konteks pada dasarnya menayakan apakah program dalam proposal kewirausahaan sesuai dengan aspek yuridis dan peluang serta potensi sekolah. Kedua, Aspek input pada dasarnya menanyakan apakah input-input kewirausahaan siap digunakan maksimal, seperti kualitas dan kuantitas personel, sarana dan prasarana pendukung, dana yang dibutuhkan, atau lainnya. Idealnya, indikator-indikator tersebut telah siap se- 
hingga kegiatan kewirausahaan yang telah direncanakan dapat efektif.

Ketiga, aspek proses pada dasarnya menanyakan apakah pelaksanaan program kewirausahaan berjalan baik, seperti proses pengelolaan, kerja sama personel, pengelolaan keuangan, keterbukaan, produksi dan pemasaran, serta lainnya. Keempat, aspek output pada dasarnya menanyakan apakah sasaran tertentu dari program kewirausahaan setelah periode waktu tertentu tercapai atau tidak, artinya dapat menghasilkan profit dalam rangka mencapai kecukupan modal untuk mendukung meningkatkan proses pendidikan serta meningkatkan proses pembelajaran di sekolah, meningkatkan gairah dalam penyelenggaraan proses pendidikan, meningkatkan produktifitas kerja serta menyejahterakan sivitas sekolah. Kelima, aspek outcome pada dasarnya menanyakan dampak program kewirausahaan, baik terhadap sekolah, siswa, dan masyarakat. Meskipun hanya dapat diukur dalam jangka panjang, paling tidak dapat diketahui melalui peningkatan kepercayaan masyarakat terhadap sekolah misalnya meningkatnya animo calon siswa baru serta dukungan dari masyarakat terhadap program.

Hasil data monitoring dan evaluasi selanjutnya dianalisis secara cermat dan mendeskribsikan setiap indikator dengan cara mencermati setiap butir program apakah sesuai dengan kondisi ideal yang ditetapkan sebelumnya. Hasil analisis diwujudkan dalam bentuk laporan yang diketahui oleh seluruh personel yang telibat sehingga dapat digunakan sebagai acuan dalam mengembangkan unit usaha lebih baik ke depan.

\section{Simpulan}

Berdasarkan hasil penelitian yang telah dilakukan maka dapat diambil beberapa kesimpulan dari hasil penelitian yaitu sebagai berikut. Pertama, syarat-syarat mendirikan Unit Kewirausahaan di SMP ISS adalah keberanian dan kemauan, pendidikan dan pelatihan tentang kewirausahaan, sikap saling percaya, bertanggung jawab dan kejujuran.
Kedua, pola pengembangan kewirausahaan sekolah meliputi tahap persiapan, yaitu mengidentifikasi lingkungan dan peluang jenis usaha di masyarakat, potensi dan kemampuan sekolah, potensi ekonomi masyarakat di sekitar sekolah. Selanjutnya tahap perencanaan, yang meliputi analisis potensi kemungkinan pengembangan, memilih dan menetapkan jenis kewirausahaan, berkunjung ke institusi usaha lokal relevan/sejenis dilanjutkan dengan penyusunan proposal kewirausahaan. Tahap pelaksanaan, dengan mendirikan unit produksi/jasa kewirausahaan, memberikan pendidikan dan pelatihan kewirausahaan terhadap siswa, serta memberi kesempatan siswa melakukan praktek kewirausahaan pada unit usaha sekolah atau usaha mitra dalam bentuk dual system education. Tahap pemasaran dilakukan oleh manajer kewirausahaan dan dibantu oleh siswa SMK. Pada tahap pemasaran ini manajer kewirausahaan masih belum terampil sehingga membutuhkan pelatihan lebih lanjut dalam hal pemasaran.

Ketiga, monitoring yang dilakukan berupa pemaparan dana awal yang digunakan, dana pemasukan yang diperoleh, belum menggunakan instrumen yang ba$\mathrm{ku}$ untuk evaluasi dan monitoring.

Berdasarkan kesimpulan yang telah dipaparkan sebelumnya, maka berikut ini akan dikemukakan beberapa saran untuk memanagemen kewirausahaan berbasis di sekolah sebagai berikut. Pertama, pemasaran produk ataupun jasa yang dihasilkan sebaiknya dilakukan oleh orang yang berkompeten pada bidangnya sehingga nantinya akan diperoleh hasil yang sangat memuaskan dan dapat meningkatkan kesejahteraan sekolah maupun para masyarakat sekolahnya.

Kedua, pengelolaan unit-unit usaha sebaiknya diberi pelatihan rutin sehingga lebih kreatif atau membuat kompetisi bagi guru-guru yang berminat menjadi penanggung jawab di unit usaha sehingga akan diperoleh mana yang lebih kreatif dan benar- benar berbakat dalam usaha. Ketiga, penanggung jawab unit usaha diberi waktu lebih banyak di unit usaha dan 
memberi konpensasi yang sesuai agar terjadi keseimbangan antara pekerjaan dan kontribusi yang diberi oleh pihak sekolah.

Keempat, manager kewirausahaan dan dibantu oleh managemen sekolah maupun yayasan dapat menjalin keraja sama dalam hal pemasaran hasil produksi unit usaha, sehingga modal dapat dikembangkan dengan cepat. Kelima, manager kewirausahaan sebaiknya memiliki kemampuan dibidang bisnis hal ini dapat diperoleh dari pendidikan agar lebih terarah.

\section{Daftar Pustaka}

Bustami. (2009). Pengaruh pengembangan profesionalisme guru SMP terhadap peningkatan mutu pendidikan di Aceh Timur. Tesis. Universitas Sumatera Utara.

Depdiknas. (1998). Kewirausahaan (enterpreneurship) dalam pendidikan: materi pelatihan calon kepala sekolah. Jakarta: Direktorat Pendidikan Menengah Umum Dirjen Dikdasmen Depdiknas.

Depdiknas. (2001). Pedoman pembinaan pengembangan kewirausahaan siswa SMK. Jakarta: Direktorat Pendidikan Menengah Kejuruan Dirjen Dikdasmen Depdiknas.

Depdiknas. Undang-Undang Nomor 20 Tahun 2003 tentang Sistem Pendidikan Nasional (2003). Jakarta.

Dharma, S., \& Akib, H. (2009). Kewirausahaan sekolah berbasis kreativitas dan inovasi. Jurnal Pendidikan Dan Kebudayaan, Edisi Khus(I), 102-117.

Engkoswara. (1999). Instructional Strategy of Civic Education at Certain School Level.
Bandung: Center for Indonesian Civic Education.

Hastuti, B. S. (2009). Pendidikan untuk pengembangan berkelanjutan (education for sustainable development). Dalam perspektif PNFI. Implementasi EfSD pada program PNFI. Androgodia. Jurnal PNFI, 1(1), 45-56.

Komalasari, K. (2011). Pembelajaran kontekstual: konsep dan aplikasi. Bandung: Refika Aditama.

Kotler, P. (1997). Manajemen pemasaran: analisis, perencanaan, implementasi dan kontrol (9th ed.). Jakarta.: PT Prenhallindo,.

Mahfud, T., \& Pardjono. (2012). Praksis pembelajaran kewirausahaan pada unit produksi jasa boga. Jurnal Pendidikan Vokasi, 2(1), 27-40. Retrieved from http://journal.uny.ac.id/index.php/j pv/article/view/1014

Moleong, L. J. (2001). Metodepenelitian kualitatif. Bandung: PT Remaja Persada Rosda Karya.

Ngadi. (2005). Model Pengembangan Kewirausahaan (Entrepreneurship) di Sekolah Melalui Strategi Berbasis Sekolah. In Modul dalam Rangka Hari Guru Nasional Internasional dengan Penyelenggara PGRI Kabupaten Sumenep Tahun 2005. Madura.

Samino. (2013). Peran kepala sekolah terhadap pengembangan kewirausahaan dalam memajukan SD Muhammadiyah Program khusus Kota Barat. Jurnal Manajemen Pendidikan, 8(2), 149 - 157. 